$\xi=-1$

\title{
Assessing Students' Level of Mastering the Federal Component of the State Educational Standard in the English and the Rus- sian Languages in Russia
}

\author{
Mariya Vasilyevna Badelina ${ }^{1 *}$, Elena Yuryevna Orekhova ${ }^{2}$ \\ ${ }^{1}$ Tyumen Industrial University, Volodarskogo St., 38, Tyumen, 625000, Russia \\ ${ }^{2}$ Institute of Humanitarian Education and Sports, Surgut State University, Lenin Avenue, 1, Surgut, 628403, Russia \\ *Corresponding author E-mail: badelina.m.v@mail.ru
}

\begin{abstract}
The purpose of the article is to consider the system of assessing the level of graduates' mastering the Federal Component of the State Educational Standard in the Russian Federation. The stated problem has been the subject of efficient research since the moment of introducing the Unified State Exam (USE) in Russia in 2005. The relevance of the study is determined by the fact that the assessment system is demonstrated through the comparative analysis of the similarities and differences between the (USE) in the Russian Language (native) and the English Language (foreign), carried out by the authors. Lately the number of students taking both an exam in Russian and English has been increasing and according to this the content and tasks in both exams have been modified. The authors describe the forms of the State Final Certification (SFC) for the English and the Russian Languages, participants, terms and duration, requirements for the USE, means of communication during the SFC, procedures for checking examination works and others. The reveals that there is a significant similarity between two types of examinations and learning both the Russian and English Languages is really important that is primarily due to the modern trends in the development of Russian society.
\end{abstract}

Keywords: assessment, control measurement materials, the English Language, the Russian Language, Unified State Examination.

\section{Introduction}

Final examinations in secondary schools, such as schools, gymnasiums, lyceums have always been considered a significant component in Soviet and later Russian system of secondary education. The unified requirement for school leavers was to pass exams in such subjects as Russian (composition) and Mathematics. Students of the 11th grade used to pass double control of the quality of knowledge at the end of school and while entering higher educational institutions of the country. It should be noted that for a long time there were no unified requirements for the structure of final exams, entrance exams, the form of their conducting, and the criteria for their assessment. Thus, school leavers passed exams twice for a short period of time.

The situation with double exams and the lack of unified requirements for the structure and forms of examinations changed in 2005. Some regions of the Russian Federation started approbation of the SFC in order to identify the conformity of the results of students' mastering basic educational programs according to the Federal State Educational Standard [9]. It was carried out in the form of the USE in a number of school subjects. School leavers passed the USE and got certificates with the results of examinations. Students from all parts of the country got a chance to enter the most prestigious universities of Russia in absentia, on the basis of the USE certificates and corresponding amount of points for required disciplines [7, 8]. In Khanty-Mansy Autonomous OkrugYugra, the USE was firstly introduced in 2005 and a lot of stu- dents got a real chance to enter universities of Moscow, St. Petersburg, Yekaterinburg, Tyumen and others.

\section{Methodology}

The given article uses modern methodology of scientific research including a set of theoretical research methods. The methods of analysis allow to decompose the USE in English and Russian into sections, study the aim, content of each section, types of tasks, number of tasks, maximum primary score for each task. The comparative method makes it possible to compare the aims, structures, types of tasks and reveal the similarities and differences between the USE in English and Russian. The method of generalization is to identify the common features of the USE in Russian (native language) and English (foreign language) in the educational process, taking into consideration the global character of the English Language, its prevalence and popularity in Russia. In addition, the study of methodological literature and statistics made it possible to trace the history of the USE introduction in Russia.

\section{Results}

Currently, the USE is annually conducted in secondary schools in the Russian Federation. The procedure for conducting the SFC on educational programs for secondary general education determines the forms of the SFC, participants, terms and duration, requirements for the USE, means of communication during the SFC, procedures for checking examination works and others. Since 
2009, the USE has been a compulsory form of final examinations at school and the main form of entrance examinations to universities, there is also a possibility of re-passing the USE in subsequent years. Compulsory educational subjects the USE is provided on are the Russian language and Mathematics. Examinations in other academic disciplines, for example, History, Social Studies or Foreign Languages, are chosen by students voluntarily [9, p. 295]. In perspective, it is planned to introduce changes in the structure of the SFC, which is dictated by the trends in the development of modern information and educational environment. For example, the changes are planned in the USE in foreign languages, in particular, since 2017 the USE in the Chinese language is expected to be introduced. In addition, the list of compulsory academic disciplines will include the USE in English.

At present it is difficult to overestimate the importance of knowing foreign languages. Firstly, knowledge of a foreign language is always desirable when hiring, travelling abroad or passing an internship in another country. Besides, it is an excellent opportunity to look for new perspectives and become an active member of international community. Universities are also interested in comprehensively developed students who are able to realize their professional potential in the process of globalization, informatization and international cooperation. That is why the USE in foreign language includes such aspects as listening, reading, grammar and vocabulary, writing, speaking. This type of examination is carried out in two stages. Firstly, students perform the oral part, which includes 4 types of tasks, then they should perform the written part consisting of listening, reading, grammar and vocabulary, writing [2]. Despite the complexity of tasks, the number of students who pass the USE in a foreign language, particularly in English, is increasing every year.

The control measurement materials (CMM) of the USE consist of a package of various kinds of communication skills and language skills testing tasks of different levels of complexity [5]. This is explained by the fact that the school educational standard provides studying a foreign language at two different levels: basic and advanced. The results of the USE in a foreign language can be used as entrance exams in a variety of specialties and areas. It is interesting that at present the results of the USE in English must be provided on an equal basis with the results of the USE in the Russian Language in many non-linguistic specialties where the knowledge of a foreign language (basic English, professional English, business English) is a part of general cultural and general professional competences Curricula. For the authors of this article, it is interesting to compare the structure of the USE in the Russian and the English Languages, taking into account the increasing popularity of foreign languages and their further introduction into the status of compulsory disciplines.

Let's consider the structure of USE in the English Language. A written part in CMM consists of 4 sections ("Listening", "Reading", "Grammar and Vocabulary", "Letter") and includes 40 tasks [4] (Table 1).

Table 1: Distribution of tasks by sections in the examination paper

\begin{tabular}{|c|c|c|c|c|c|}
\hline No & Section & $\begin{array}{c}\text { Number } \\
\text { of the } \\
\text { tasks }\end{array}$ & $\begin{array}{c}\text { Maximum } \\
\text { primary } \\
\text { score }\end{array}$ & $\begin{array}{c}\text { Percentage of } \\
\text { maximum } \\
\text { primary score } \\
\text { for performing } \\
\text { tasks in this } \\
\text { section from } \\
\text { maximum } \\
\text { primary score } \\
\text { for the entire } \\
\text { work of } 100\end{array}$ & $\begin{array}{c}\text { Type of } \\
\text { tasks }\end{array}$ \\
\hline 1. & Listening & 9 & 20 & 20 & $\begin{array}{c}\text { Short } \\
\text { answer } \\
\text { tasks }\end{array}$ \\
\hline 2. & Reading & 9 & 20 & 20 & $\begin{array}{c}\text { Short } \\
\text { answer } \\
\text { tasks }\end{array}$ \\
\hline 3. & $\begin{array}{c}\text { Grammar } \\
\text { and vocab- }\end{array}$ & 20 & 20 & 20 & $\begin{array}{c}\text { Short } \\
\text { answer }\end{array}$ \\
\hline
\end{tabular}

\begin{tabular}{|c|c|c|c|c|c|}
\hline 4. & ulary & & & & tasks \\
\hline Writing & 2 & 20 & 20 & $\begin{array}{c}\text { Tasks } \\
\text { with } \\
\text { complete } \\
\text { answer }\end{array}$ \\
\hline \multicolumn{2}{|c|}{ Total } & 40 & 80 & 80 & \\
\hline
\end{tabular}

The first section "Listening" contains 9 tasks: the first task checks the skill of comprehending the main content of the text; the second task is aimed at controlling the development of the skill to comprehend the requested information in the text; in the third task students should demonstrate a complete comprehending of the text. The recommended time for section 1 is 30 minutes. The second section "Reading" includes 9 tasks. The first task is to check the development of such a skill as understanding the main content of the text; the second task is aimed at checking the understanding of structural and semantic links in the text; the third task controls complete and accurate understanding of the information in the text The recommended time for section 2 is 30 minutes. The third section "Grammar and vocabulary" contains 20 tasks. The first task is to control the development of grammatical skills; the second and third tasks are supposed to test lexical and grammatical skills. The recommended time for section is 40 minutes. The fourth section in the written part of the USE "Writing" includes 2 tasks and controls the skill to create different types of written texts [6, pp. 5-6] (Table 2).

Table 2: Distribution of tasks in the examination paper due to the content and types of skills

\begin{tabular}{|c|c|c|c|}
\hline Checked skills & $\begin{array}{l}\text { Number } \\
\text { of the } \\
\text { tasks }\end{array}$ & $\begin{array}{l}\text { Maximum } \\
\text { primary } \\
\text { score }\end{array}$ & $\begin{array}{l}\text { Percent of the } \\
\text { maximum } \\
\text { score of } 100\end{array}$ \\
\hline \multicolumn{4}{|c|}{ Written part } \\
\hline \multicolumn{4}{|c|}{ 1. Listening } \\
\hline $\begin{array}{l}\text { Comprehending the main } \\
\text { content of the text }\end{array}$ & 1 & 6 & \multirow{3}{*}{20} \\
\hline $\begin{array}{l}\text { Comprehending the re- } \\
\text { quested information in the } \\
\text { text }\end{array}$ & 1 & 6 & \\
\hline $\begin{array}{l}\text { Complete comprehending } \\
\text { the text }\end{array}$ & 1 & 7 & \\
\hline \multicolumn{4}{|c|}{ Reading } \\
\hline $\begin{array}{l}\text { Understanding the main } \\
\text { content of the text }\end{array}$ & 1 & 6 & \multirow{3}{*}{20} \\
\hline $\begin{array}{l}\text { Understanding structural } \\
\text { and semantic links in the } \\
\text { text }\end{array}$ & 1 & 6 & \\
\hline $\begin{array}{l}\text { Complete and accurate } \\
\text { understanding of the in- } \\
\text { formation in the text }\end{array}$ & 7 & 7 & \\
\hline \multicolumn{4}{|c|}{ Grammar and vocabulary } \\
\hline Grammatical skills & 7 & 7 & \multirow{3}{*}{20} \\
\hline $\begin{array}{l}\text { Lexical and grammatical } \\
\text { skills }\end{array}$ & 6 & 6 & \\
\hline $\begin{array}{l}\text { Lexical and grammatical } \\
\text { skills }\end{array}$ & 7 & 7 & \\
\hline \multicolumn{4}{|c|}{ Writing } \\
\hline Personal letter & 1 & 6 & \\
\hline $\begin{array}{l}\text { Written statement with } \\
\text { elements of reasoning on } \\
\text { the proposed problem }\end{array}$ & 1 & 14 & 20 \\
\hline
\end{tabular}

It should be noted that the tasks of CMM are related to different levels of complexity. For example, the tasks in the sections "Listening" and "Reading" refer to different levels of complexity: basic, higher level and advanced [2]. The tasks in two other sections "Grammar and Vocabulary", as well as "Reading" refer to the basic and high levels of complexity. Thus, a clear grading of the tasks of the CMM on three levels of complexity makes it possible to distribute tasks according to the increasing degree of complexity and to determine the level of the development of school graduates' skills (Table 3 ). 
Table 3: Distribution of tasks in the examination paper due to the level of complexity

\begin{tabular}{|c|c|c|}
\hline Checked skills & $\begin{array}{c}\text { Number of } \\
\text { the task }\end{array}$ & $\begin{array}{c}\text { Level of com- } \\
\text { plexity }\end{array}$ \\
\hline \multicolumn{2}{|c|}{ Listening } \\
\hline $\begin{array}{c}\text { Comprehending the main content of the } \\
\text { text }\end{array}$ & 1 & basic \\
\hline $\begin{array}{c}\text { Comprehending the requested infor- } \\
\text { mation in the text }\end{array}$ & 2 & advanced \\
\hline Complete comprehending the text & 3 & basic \\
\hline \multicolumn{2}{|c|}{ Reading } \\
\hline $\begin{array}{c}\text { Understanding the main content of the } \\
\text { text }\end{array}$ & 1 & higher level \\
\hline $\begin{array}{c}\text { Understanding structural and semantic } \\
\text { links in the text }\end{array}$ & 2 \\
\hline $\begin{array}{c}\text { Complete and accurate understanding } \\
\text { of the information in the text }\end{array}$ & 3 \\
\hline \multicolumn{2}{|c|}{ Grammar and vocabulary } \\
\hline Grammatical skills & 1 & basic \\
\hline Lexical and grammatical skills & 2 & basic \\
\hline Lexical and grammatical skills & 3 & advanced \\
\hline \multicolumn{2}{|c|}{ Writing } \\
\hline $\begin{array}{c}\text { Written statement with elements of } \\
\text { reasoning on the proposed problem }\end{array}$ & 2 \\
\hline
\end{tabular}

In comparison with English, the CMM structure in the Russian language, which is the state language of the Russian Federation, at first glance, is simpler. So, each variant of the task includes two parts. The first part consists of 24 tasks of two levels of complexity - basic (21 tasks) and advanced (3 tasks) [3]. Previously, this part of the CMM was highly criticized, since the tasks were constructed in the form of a classical test with the option of choosing one correct answer from four variants [4]. Therefore, this part of the examination paper was called "solving a puzzle". Since 2015, the tasks have been made more complicated. In particular, the tasks of an open type, explicating the ability of students to give a verbal record of the correct answer have been introduced. The closed-type tasks have become more diverse: a) with the choice of one correct answer (multiple choice), b) with the possibility of selecting several answers (alternative choice), c) with the ability to correlate the original job with the correct option (task for restoring compliance). Such assignments make it possible to assess school graduates' knowledge comprehensively and check the level of students' practical communicative skills proficiency and the knowledge of the most important norms of the Russian literary language [1].

The second part of CMM in the Russian Language "CompositionReasoning" is an open-type task. It is a task of higher complexity, that is understandable and reasonable. The composition is a productive task, including a creative component. The student should give a detailed answer according to a given pattern: formulate the problem by supporting the text, comment on it, identify the position of the author of the source text, express his/her opinion, give examples and illustrations from fiction or journalistic literature Thus, this part of the examination paper allows to appraise the level of various speech skills that were shaped in the educational process and form the basis of students' communicative competence [10] (Tables 4, 5). In addition, the graduate demonstrates the knowledge of the functional-stylistic features of the text, the genre characteristics of the "Composition-Reasoning", the ability to compose a monologic text, as well as the knowledge of various language norms. It should be noted that for Russia the composition was the traditional form of knowledge and skills assessment in the Russian Language. This form of the exam is to chech how well the student has mastered the theoretical and practical material on the subject, and most importantly, if he has learned to think and compose a coherent text. It is the composition that reflects the school graduates' vocabulary, the skill to apply knowledge acquired in other humanitarian subjects (primarily in Literature and History), which is so necessary for future young professionals.
Table 4: Distribution of tasks in the examination paper in the Russian Language

\begin{tabular}{|c|c|c|c|c|}
\hline Section & $\begin{array}{c}\text { Number } \\
\text { of the } \\
\text { tasks }\end{array}$ & $\begin{array}{c}\text { Maximum } \\
\text { primary } \\
\text { score }\end{array}$ & $\begin{array}{c}\text { Percentage of maxi- } \\
\text { mum primary score } \\
\text { for performing tasks } \\
\text { in the section from } \\
\text { maximum primary } \\
\text { score for the entire } \\
\text { work of } 58\end{array}$ & $\begin{array}{c}\text { Type of } \\
\text { tasks }\end{array}$ \\
\hline $\begin{array}{c}\text { Section } \\
1\end{array}$ & 25 & 34 & 59 & $\begin{array}{c}\text { Short } \\
\text { answer } \\
\text { tasks }\end{array}$ \\
\hline $\begin{array}{c}\text { Section } \\
2\end{array}$ & 1 & 24 & 41 & $\begin{array}{c}\text { Tasks with } \\
\text { complete } \\
\text { answer }\end{array}$ \\
\hline Total & 26 & 58 & & \\
\hline
\end{tabular}

Table 5: Distribution of tasks in the examination paper due to the content and types of skills

\begin{tabular}{|c|c|c|c|c|}
\hline Content sections & $\begin{array}{l}\text { Number } \\
\text { of the } \\
\text { tasks }\end{array}$ & $\begin{array}{c}\text { Maximum } \\
\text { primary } \\
\text { score }\end{array}$ & $\begin{array}{l}\text { Percentage of } \\
\text { maximum } \\
\text { primary score } \\
\text { for performing } \\
\text { tasks in the } \\
\text { section from } \\
\text { maximum } \\
\text { primary score } \\
\text { for the entire } \\
\text { work of } 58\end{array}$ & $\begin{array}{l}\text { Level of } \\
\text { complexity }\end{array}$ \\
\hline $\begin{array}{l}\text { Speech. Text. Skill } \\
\text { to carry out infor- } \\
\text { mation processing } \\
\text { of the text and abil- } \\
\text { ity to conduct lin- } \\
\text { guistic analysis of } \\
\text { texts }\end{array}$ & 5 & 6 & 11 & $\begin{array}{c}\text { basic (4) } \\
\text { advanced } \\
(1)\end{array}$ \\
\hline $\begin{array}{l}\text { Vocabulary and } \\
\text { phraseology. Skill to } \\
\text { apply basic lexical } \\
\text { norms of modern } \\
\text { Russian literary } \\
\text { language in practice }\end{array}$ & 2 & 2 & 3 & basic (2) \\
\hline $\begin{array}{l}\text { Speech. Norms of } \\
\text { spelling. Skill to } \\
\text { apply in practice } \\
\text { spelling norms of } \\
\text { modern Russian } \\
\text { literary language }\end{array}$ & 7 & 7 & 12 & basic (7) \\
\hline $\begin{array}{l}\text { Speech. Norms of } \\
\text { punctuation. Skill to } \\
\text { apply punctuation } \\
\text { norms of modern } \\
\text { Russian literary } \\
\text { language }\end{array}$ & 5 & 6 & 11 & basic (5) \\
\hline $\begin{array}{l}\text { Speech. Language } \\
\text { norms. Skill to } \\
\text { apply grammatical } \\
\text { norms of modern } \\
\text { Russian literary } \\
\text { language in practice, } \\
\text { to analyze errors }\end{array}$ & 5 & 9 & 15 & $\begin{array}{l}\text { basic (4), } \\
\text { advanced } \\
(1)\end{array}$ \\
\hline $\begin{array}{l}\text { Speech. Expressive- } \\
\text { ness of Russian } \\
\text { speech. Skill to } \\
\text { qualify expressive } \\
\text { means and to corre- } \\
\text { late their functions }\end{array}$ & 1 & 4 & 7 & $\begin{array}{l}\text { advanced } \\
\text { (1) }\end{array}$ \\
\hline $\begin{array}{l}\text { Development of } \\
\text { speech. Composi- } \\
\text { tion. } \\
\text { Skill to create own } \\
\text { statement on the } \\
\text { basis of the read text } \\
\text { and to carry out } \\
\text { speech self-control }\end{array}$ & 1 & 24 & 41 & $\begin{array}{c}\text { basic, } \\
\text { advanced, } \\
\text { higher } \\
\text { level }\end{array}$ \\
\hline Total & 26 & 58 & 100 & \\
\hline
\end{tabular}




\section{Conclusion}

The system of assessing the students' level of mastering the Federal component of the State Educational Standard in the English and the Russian Languages in the Russian Federation is annually being altered. Ministry of Education and Science of the Russian Federation, Federal Institute of Pedagogical Measurements, Departments of Education and Youth Policy and Schools for Advanced Studies at the regional level are organizing a great number of programmes and training courses for teachers and organizers to improve the procedure of conducting the USE in Russia. The comparative analysis of the aims, tasks in CMM in English and Russian makes it possible to conclude that the structures, types of tasks, levels of complexity correlate with each other to some extent. The commonality in the tasks "Writing" (English) and "Part 2. Composition-Reasoning" (Russian language) has drawn the attention of the authors. This similarity is quite understandable, since it is the composition that reflects the process of the student's speech activity, which constitutes the material basis of communication. Also, the identity of tasks can be clearly seen in sections 2 ("Reading"), 3 ("Grammar and vocabulary") of CMM in English and "Part 1" of CMM in the Russian language. Due to the modern trends in the development of Russian society in the whole and the system of education in particular, the authors consider it obvious that the development of the foreign communicative competence including speech, language, sociocultural, compensatory, educational and cognitive components is as important and essential as the knowledge and skills in the Russian Language. The development and formation of understanding the importance of studying foreign languages in the modern world and the need to use it as a means of communication, cognition, self-realization and social adaptation allow to develop national self-awareness, aspirations for mutual understanding between people of different communities, tolerant attitude towards manifestations of a different culture. So, the procedures of assessing the students' level of mastering the Federal Component of the State Educational Standard in the English and the Russian Languages in Russia are common in some aspects.

\section{References}

[1] Codifier of elements of content and work in the lessons of preparatory issues of educational organizations for evidence of the Unified State Examination in the Russian language (2017). Moscow.

[2] Demos, specifications, codifiers (2016). Available online: http://www.fipi.ru/sites/default/files/document/1448529404/yaa.zip.

[3] Demonstration version of the control and measuring materials of the Unified State Examination in the Russian language in 2017 (2017). Moscow

[4] Demonstration version of the control and measuring materials of the Unified State Examination in the Russian language in 2013. Moscow, 2013.

[5] The Order of the Ministry of Education and Science of Russia (December 26, 2013). On approval of the procedure for conducting the final state certification on educational programs of secondary general education.

[6] Specification of CMM for holding a Unified State Examination in foreign languages in 2017 (2016). Moscow, 7.

[7] Verbitskaya MV, Makhmuryan KS, Simkin, VN (2015), Methodical recommendations for teachers, prepared on the basis of the analysis of typical errors of the participants of the Unified State Examination of 2015 in Foreign Languages. Moscow, 2.

[8] Verbitskaya MV, Makhmuryan KS (2016), The English language. Methodical recommendations for assessing the performance of tasks of the oral part of the USE. Moscow, 2.

[9] Orekhova EYu, Sergienko NA (2016), The technology of preparing students for tasks with complete answer in the written part of the Unified State Exam in English. Achievements and prospects for the development of science. Ufa: AETERNA, 295.

[10] Tsybulko IP, Vasilevykh IP, Aleksandrov VN (2016), The Russian Language. I'll pass the exam! The modular course. Training methodology. Moscow: Prosveshchenie, 112. 